\title{
Effect of Transformational Leadership Style and Work Commitment on Employee Performance at the Regional Secretariat of Murung Raya Regency, Central Kalimantan Province
}

\author{
Yohana $^{1}$, Humaidi ${ }^{2}$ \\ ${ }^{1}$ Study Program in Public Administration, Faculty of Social and Political Sciences, Lambung Mangkurat \\ University, Banjarmasin City, South Kalimantan, Indonesia \\ ${ }^{2}$ Study Program in Business Administration, Faculty of Social and Political Sciences, Lambung Mangkurat \\ University, Banjarmasin City, South Kalimantan, Indonesia
}

\begin{tabular}{l} 
Article Info \\
\hline Article history: \\
Received Oct 12, 2021 \\
Revised Dec 10, 2021 \\
Accepted Dec 25, 2021 \\
\hline
\end{tabular}

\section{Keywords:}

Transformational Leadership Style

Work Commitment

Employee Performance

\begin{abstract}
This study aims to determine the Effect of Transformational Leadership Style and Work Commitment on Employee Performance at the Regional Secretariat of Murung Raya Regency, Central Kalimantan Province. The technique used in this study is SmartPLS Analysis using the help of the SmartPLS package computer program with a significance level of 5 percent by using questionnaires as primary data. The population in this study were employees of the Regional Secretariat of Murung Raya Regency as many as 192 people with a sample of the same number as many as 192 respondents who used saturated sampling techniques, that is, the entire population was sampled.

The results of this study indicate that partially transformational leadership style and work commitment have a significant effect on employee performance, this means that an increase in transformational leadership style and work commitment will improve employee performance at the Murung Raya Regency Regional Secretariat. To maintain employee performance at the Murung Raya Regency Secretariat, it can be done by using transformational leadership styles and managing work commitments. It is important to take actions that can improve work commitment and employee performance
\end{abstract}

This is an open access article under the CC BY-SA license.

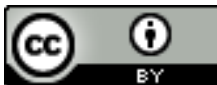

\section{Corresponding Author:}

Humaidi

Study Program in Business Administration,

Faculty of Social and Political Sciences, Lambung Mangkurat University, Banjarmasin

Jl. Brigjen H. Hasan Basry. Kayu Tangi

Email: humaidi.bisnis@ulm.ac.id

\section{INTRODUCTION}

Leadership is an important topic in any research directed at reviewing an organization. Within an organization, the character of a leader and the style applied in his leadership have a profound influence on the course of the organization and the survival of the organization. In an organization, a good job strategy is not sufficient, nowadays the existence of a reliable leader is needed by the organization to support the strategy. Because it is the leader who will give birth to the strategy and at the same time work hard in order to realize that strategy. A leader who is considered successful is a leader who is responsive to circumstances, situations, 
to changes to the organization he leads so that he can maximize all the resources contained in it and produce good organizational performance [1 ][2]

Until now there are many concepts about leadership expressed by some experts. Leadership is described in several terms based on the characteristics and actions taken, ranging from charismatic leadership, transactional leadership, to the most recent term that is widely proposed is transformational leadership, which is now widely applied by some organizational leaders. The transformational leadership model is a relatively new model in leadership studies. This model is considered to be the best model in explaining the characteristics of the leader. The concept of transformational leadership integrates ideas developed in a character, style and contingency approach. The essence of transformational leadership is the sharing of power. In this concept, a transformational leader engages subordinates together to change, or often called an empowerment. Through transformational leadership there is a positive attraction between superiors and subordinates [3][4][5].

Transformational leaders must be able to define, communicate and articulate the vision of the organization, and subordinates must accept and recognize the credibility of their leaders. Transformational leaders must also have the ability to equate future vision with their subordinates, as well as heighten subordinates' needs at a higher level than what they need. The existence of transformational leaders has a transformational effect both at the organizational level and at the individual level. Transformational leadership has the ability to bring enormous change to individuals and organizations in a way: reinventing the character of individuals in the organization or organizational improvement, initiating the process of creating innovation, revisiting organizational structures, processes and values to be better and more relevant, in ways that are attractive and challenging to all involved, and try to realize organizational goals that have been considered impossible to implement. Such a leader can understand the importance of fundamental and major changes in their lives and work in achieving the results they desire.6][7]

Transformational leadership, leaders create vision, environment and provide motivation to subordinates to excel. The implication is that subordinates will feel amazed, trusting and committed to the leader [7]. This is what shows transformational leadership has a positive impact on subordinate performance. The leadership style in this study refers to the transformational leadership style applied by the leadership elements, both Echelon II, Echelon III and Echelon IV at the Regional Secretariat of Murung Raya Regency. One indicator of transformational leadership style is to apply a pattern of openness that makes the leadership element in the work units in the Regional Secretariat of Murung Raya Regency can obtain information from the lowest level to the highest level starting with communication and respecting outstanding employees. In addition, the leadership element in the Regional Secretariat of Murung Raya Regency emphasizes to employees to think outside the context of existing thinking, because to improve performance not only looking at human resources in terms of quantity, but in improving quality through development and training to improve employee competence, so that there are currently so many employees in the Regional Secretariat who have certificates from Education and training related to certificates in the field of government, reporting and finance to procurement of goods and services.

Human resource development strategies through transformational leadership styles that are consistently applied proved to produce quite good results, where this is seen in the performance of employees of the Murung Raya District Secretariat in implementing and realizing performance that leads to high budget absorption as an implication of the implementation of all programs and work activities in each budget year. The average budget absorption of the Regional Secretariat of Murung Raya Regency ranges from 90\%, one of which in fiscal year 2018 reached $97.15 \%$ (data based on the 2018 Budget Realization Report). Every year there is always an increase in absorption which means also that performance increases every year [8].

The diagnosis of organizational development holds that the progress and success of the organization depends largely on the Employees. The extent which the employee is able and willing to work hard, creative, innovative, loyal, disciplined, honest and responsible will determine the achievements of the organization. Therefore, to know the extent which employees work, the leadership of the organization needs to know how the attitude and behavior of its employees. Attitudes will reflect a person's behavior. But to know how a person's attitude is not easy, because attitude is influenced by many factors such as perception, motivation, environment and others.

Employee commitment is defined by some researchers as a measure of the strength of an employee's identity and involvement in an organization's goals and values. Employee commitment is obtained as a better indicator of "leavers" and "stayers" than job satisfaction. Other research found that job satisfaction was related to the task environment, while employee commitment was related to achievements on organizational empowerment.[10][11] With the commitment given, it is expected that the performance of employees will increase, employee commitment as an attitude that reflects employee loyalty to the organization and is an ongoing process in which members of the organization express their concern for the organization, to the success of the organization and continued progress. 
If the perception of a person shows as a leader who deserves to be loved, trusted, followed, able to guide and meet the criteria of leaders who are able to provide a representation of the heart, then it will affect the magnitude of work, organizational commitment and employee performance. Therefore, the leader must have the ability. Without ability, people wouldn't be willing to follow and listen to that [11]. Therefore, the leader must be able to arouse the respect and sympathy of others. Employee work commitment must be maintained in order to achieve the goals of the organization. It is also done at the Regional Secretariat of Murung Raya Regency, the work commitment to this organization is very important because it contributes to the success of organizational performance, it can improve quality public services. To realize this, the Regional Secretariat of Murung Raya Regency is committed to (1) Creating transparency in the application of disciplines that start from oneself, civilizing behavior and developing competence through the development of effective work attitudes, (2) Complying with applicable laws and regulations, (3) Taking good and continuous performance measurements, both through the assessment of Employee Performance Goals (SKP), as well as through community assessment with the media. Community Satisfaction Index Survey which produces data on Community Satisfaction Index (IKM) on services provided by work units at the Regional Secretariat of Murung Raya Regency.

Employee work commitments at the Regional Secretariat of Murung Raya Regency can be seen through the list of employee attendance that is orderly and rarely arrives late. Orderly implementation of morning ceremony and afternoon attended by elements of leadership and employees. For creating discipline in carrying out work duties, the presence of employees is important because it can show that employees have a responsibility to the work organization. In the other hand, the ability to lead in moving and empowering employees will affect performance. Leaders have a significant impact on employee attitudes, behavior and performance. The effectiveness of the leader is influenced by the characteristics below and related to the communication process that occurs between the leader and his subordinates. Leaders are said to be unsuccessful if they are unable to motivate, move and satisfy employees in a particular job and environment. The task of the leader is to encourage subordinates to have competence and opportunities to develop in anticipating every challenge and opportunity in work. Employee work can be seen from two sides, namely internal, (through the study of work motivation of the employee itself) and external (in the study of the employee's work environment) [11][13].

Noting the above, it is seen that the importance of understanding transformational leadership styles and work commitments in an effort to improve the performance of staffers at the Regional Secretariat of Murung Raya Regency. This is considering that the Regional Secretariat of Murung Raya Regency is one of the Large Regional Device Organization Units within the scope of a regency that will determine the success of government implementation in accordance with the vision and mission of Murung Raya Regency.

\section{RESEARCH METHOD}

The approach used in this research is quantitative approach i.e., i.e. research methods based on the philosophy of positivism, used to examine in a particular population or sample, sampling techniques in general at random, data collection using research instruments, quantitative / statistical data analysis with the aim to test established hypotheses. Quantitative data is data expressed in the form of numbers, or qualitative data that is guessed. The research process is deductive, i.e. by using propositions that are general in nature, then making conclusions that are seen as consequent to the enactment of truth in the general proposition earlier [14].

The type of research used is associative causality because the purpose of the study is to test the effect (determinant) of one or more independent variables against one or more dependent variables. Associative is a research statement that asks the relationship between two or more variables. Causal are causal relationships. So here are independent variables (influencing variables) and dependent variables (variables affected)[14][15].

Population is the entire combined of employees who are expected to be used to make decisions. In this study, the population that will be observed at the Regional Secretariat of Murung Raya Regency amounted to 192 employees, with various classifications of positions, echelonizations and staff. The technique of determining samples from a population of 192 employees in the Regional Secretariat of Murung Raya Regency, which is used is by saturated sampling, namely the entire population used as a sample.

The scale measurement technique in this study used the likert scale. The use of this likert scale is based on appropriate uses for measuring the opinions, attitudes and perceptions of a person or group of people aboutsocialproblems. Pls analysis model data analysis technique (Partial Least Square) using the help of SmartPLS package computer program[17] Systematically the steps in the analysis with PLS are Step One: Designing a Structural Model (inner model), Step Two: Designing a Measurement Model (outer model), Step Three: Constructing a Pathdiagram, Step Four: Conversion of Path diagrams into Equation Systems, Fifth Step: Estimation, Sixth Step: Evaluation of Goodness of Fit and Step Seventh: Hypothesis Testing [17][18][19]. 


\section{RESULTS AND DISCUSSION}

Testing the validity and reliability of instruments in PLS is an outer model test. An outer model or measurement model, in principle, is to test a grain against a latent construct, or in other words measure how far it can explain its latent construct. Reflective indicators and grains are measured by convergent validity, discriminant validity or by Average variance extracted (AVE), and composite reliability. In a variant-based SEM model or PLS-Path Modeling, this model test consists of two stages, namely: 1) outer model test (model validity and reliability test) and 2) Inner model test (influence testing between variable-hypotheses). A good and reliable question point is one that proves valid and reliable in measuring variables after being tested statistically[18][20].

\subsection{Testing validity and reliability}

The validity and reliability test is done three times, this is because the first and second structural models have not met the requirements of analysis, such as invalid items, and AVE less than 0.5, then the first and second structural models must be modified, by discarding invalid items. The outer test of stage three structural models is performed by discarding invalid latent variable items on the first and second models, namely items that have convergent validity values of less than 0.50 , and indicators that have discriminate validity values of less than $0.50[17]$

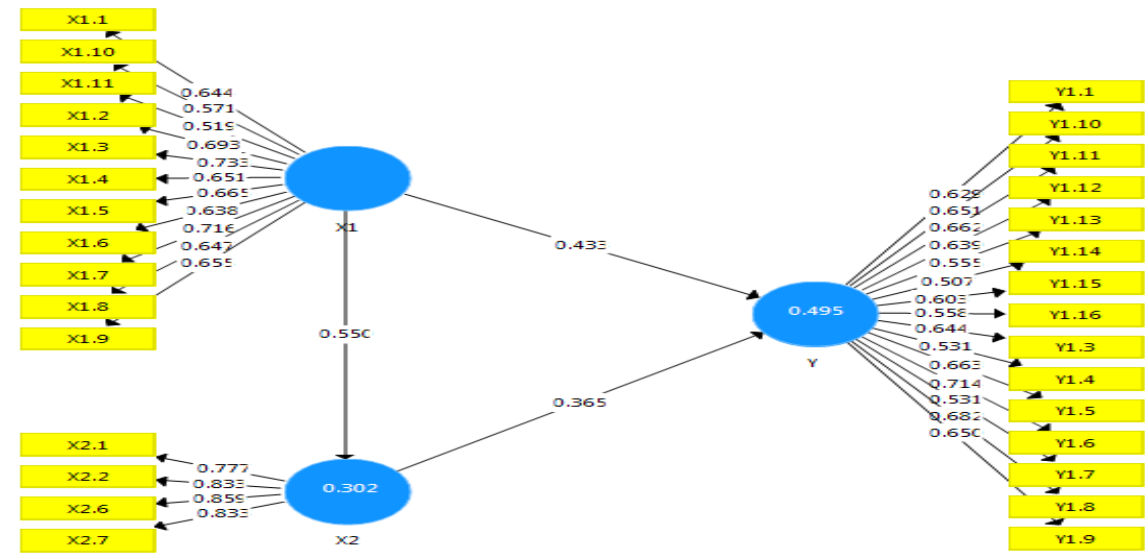

Figure 1. Structural Outer Model Test

Source: SmartPLS output, 2021

The results of the outer loadings (convergent validity) test for structural models to the three results of modifications of the first model and the second against the latent variable indicator show the entire indicator valid because the outer loading value is greater than $0.50[17]$

Table 1. Convergent validity third model

\begin{tabular}{|c|c|c|c|c|c|}
\hline Grain & $\begin{array}{c}\text { Transformational } \\
\text { Leadership Style }\end{array}$ & $\begin{array}{c}\text { Commitmen } \\
\mathbf{t}\end{array}$ & $\begin{array}{c}\text { Employee } \\
\text { Performa } \\
\text { nce }\end{array}$ & Standard & Grain \\
\hline X1.1 & 0,644 & & & $>0.5$ & Valid \\
\hline X1.10 & 0,571 & & & $>0.5$ & Valid \\
\hline X1.11 & 0,519 & & & $>0.5$ & Valid \\
\hline X1.2 & 0,693 & & & $>0.5$ & Valid \\
\hline X1.3 & 0,733 & & & $>0.5$ & Valid \\
\hline X1.4 & 0,651 & & & $>0.5$ & Valid \\
\hline X1.5 & 0,665 & & & $>0.5$ & Valid \\
\hline X1.6 & 0,638 & & & $>0.5$ & Valid \\
\hline X1.7 & 0,716 & & & $>0.5$ & Valid \\
\hline X1.8 & 0,647 & & & $>0.5$ & Valid \\
\hline X1.9 & 0,655 & & & $>0.5$ & Valid \\
\hline X2.1 & & 0,777 & & $>0.5$ & Valid \\
\hline X2.2 & & 0,833 & & $>0.5$ & Valid \\
\hline
\end{tabular}

Effect of Transformational Leadership Style and Work Commitment on Employee Performance at the Regional Secretariat of Murung Raya Regency, Central Kalimantan Province 


\begin{tabular}{|c|c|c|c|c|c|}
\hline Grain & $\begin{array}{c}\text { Transformational } \\
\text { Leadership Style }\end{array}$ & $\begin{array}{c}\text { Commitmen } \\
\mathbf{t}\end{array}$ & $\begin{array}{c}\text { Employee } \\
\text { Performa } \\
\text { nce }\end{array}$ & Standard & Grain \\
\hline X2.6 & & 0,859 & & $>0.5$ & Valid \\
\hline X2.7 & 0,833 & & $>0.5$ & Valid \\
\hline Y1.1 & & & 0,629 & $>0.5$ & Valid \\
\hline Y1.10 & & 0,651 & $>0.5$ & Valid \\
\hline Y1.11 & & 0,662 & $>0.5$ & Valid \\
\hline Y1.12 & & 0,639 & $>0.5$ & Valid \\
\hline Y1.13 & & 0,555 & $>0.5$ & Valid \\
\hline Y1.14 & & 0,507 & $>0.5$ & Valid \\
\hline Y1.15 & & 0,603 & $>0.5$ & Valid \\
\hline Y1.16 & & & 0,558 & $>0.5$ & Valid \\
\hline Y1.3 & & & 0,644 & $>0.5$ & Valid \\
\hline Y1.4 & & & 0,531 & $>0.5$ & Valid \\
\hline Y1.5 & & & 0,714 & $>0.5$ & Valid \\
\hline Y1.6 & & & 0,531 & $>0.5$ & Valid \\
\hline Y1.7 & & & 0,682 & $>0.5$ & Valid \\
\hline Y1.8 & & & & $>0.5$ & Valid \\
\hline Y1.9 & & & & \\
\hline
\end{tabular}

Source: SmartPLS output, 2021

Based on table 1. Known values of outer loading (convergent validity)against the details of research variables show all questions over research variables proved valid. For transformational Leadership Styles there are eleven (11) valid items, Work Commitment there are four (4) valid items, and Performance there are fifthteen (15) valid items.

Another method for viewing discriminat validity is to look at the square root value of average variance extracted $(A V E)$. The recommended minimum value is 0.5 . Here is the first model $A V E$ value.

Table 2. Fourth Model AVE Value

\begin{tabular}{|l|c|c|c|}
\hline \multicolumn{1}{|c|}{ Variable } & AVE & $\begin{array}{c}\text { Minimum } \\
\text { Standards }\end{array}$ & Criterion \\
\hline Transformational Leadership Style & 0.724 & 0,5 & Valid \\
\hline Work Commitment & 0.882 & 0,5 & Valid \\
\hline Employee Performance & 0.681 & 0,5 & Valid \\
\hline
\end{tabular}

Source: smartPLS output, 2021

Table 2 shows the AVE value obtained showing the entire latent construct proved to be valid, since the AVE value of each construct is greater than 0.5 (the minimum standard value in smartPLS). This indicates that the entire latent construct item has had a high internalconsistency[20].

Reliability measurements are done using composite reliability and Cronbachs Alpha. The minimum values for both are 0.7 and 0.6 . The measurement results can be seen in table 3 .

Table 3. Composite Reliability And Cronbachs Alpha Model 3

\begin{tabular}{|l|c|c|c|c|}
\hline \multicolumn{1}{|c|}{ Construct } & $\begin{array}{c}\text { Composite } \\
\text { Reliability }\end{array}$ & $\begin{array}{c}\text { Cronbachs } \\
\text { Alpha }\end{array}$ & $\begin{array}{c}\text { Minimum } \\
\text { Standards }\end{array}$ & Criterion \\
\hline Transformational Leadership Style & 0.864 & 0.869 & 0,6 & Reliable \\
\hline Work Commitment & 0.847 & 0.855 & 0,6 & Reliable \\
\hline Employee Performance & 0.883 & 0.884 & 0,6 & Reliable \\
\hline
\end{tabular}

Source: smartPLS output, 2021

Table 3. above shows all research variables have good reliability, because it has composite reliability of more than 0.7 and alpha above 0.6

\subsection{Linearity Assumption Test Results}

Hypothesis testing on SmartPLS is done by resampling approach with the Bootstrap method, so it does not require assuming the normality of the data. The assumption required on SmartPLS is that the form of influence between variables must be linear. The assumption of linearity itself is an assumption that states that 
the influence between variables to be analyzed follows a straight line so that if the regression equation obtained is made graph, it will look graph in the form of linear lines. The assumptions on SmartPLS relate only to the modeling of structural equations, and are not related to hypothesis testing, namely: The influence between variables in structural models is linear and additive. This assumption test can be done with the Ramsey test or using Curve Fit. Both of these methods can be calculated using SPSS software[20][21]

To test the assumption of linearity will be used ANOVA table analysis and will be seen sig values. linearity \& sig. Deviation from linearity of any variable is free with variables bound in contrast to the level of significance $(\alpha)$. Sig value. Linearity shows the degree to which free variables are compared precisely in a straight line. If the value of sig. linearity is less than the level of significance $(\alpha)$, then linear regression can be used to explain the influence between existing variables. While the value sig. deviation from linearity shows what data is used [21]. Testing this assumption is done with the help of SPSS software and the full results can be seen in the following table.

Table 4. Results of Linearity Assumption Testing

\begin{tabular}{|c|l|l|c|l|}
\hline \multirow{2}{*}{ No. } & \multicolumn{2}{|c|}{ Influence between Variables } & $\begin{array}{c}\text { Linearity } \\
\text { (p-value) }\end{array}$ & Criterion \\
\hline 1 & Transformational Leadership Style & Employee Performance & 0,000 & Linear \\
\hline 2 & Work Commitment & Employee Performance & 0,000 & Linear \\
\hline 3 & Transformational Leadership Style & Work Commitment & 0,000 & Linear \\
\hline
\end{tabular}

Source: Processed from primary data, 2021

Based on the table it can be known that all influences between variables are linear, thus the assumption of linearity on this research model is met.

\subsection{Hypothesis Testing with SEM PLS}

Partial Least Square (PLS) according to would be a powerful method of analysis because it is not based on many assumptions. PLS as a data analysis technique with SmartPLS software version 2.0.M3 has its own advantages including: data does not have to be distributed normally multivariate (indicators with category scale, ordinal, interval to ratio can be used on the same model) and the sample size does not have to be large. Although PLS is used to confirm theories, it can also be used to explain the or absence of relationships between latent variables. PLS can analyze at once constructs formed with reflexive indicators and formative indicators and this is not possible in the Structural Equation Model (SEM) because it will occur unidentified models[17][18][21].

Inner model or structural model testing in principle tests the influence between one latent variable and another latent variables both exogenous and endogenous. It can also be said to test hypotheses between one latent variable and another latent variable. The test is done by looking at the percentage of variants described, namely: ${ }^{\mathrm{R} 2}$ for dependent latent variables modeled to get the influence of independent latent variables using the stone-geisser size $Q$ square test, and look at the magnitude of the coefficient ofthe structural path. The stability of this estimate is tested using t-statistics obtained through the bootstrapping procedure.[21]

Significant testing of the partial effect of each exogenous variable on endogenous variables is done by comparing the value of $t$ calculation statistics with $t$ significance. If the T-statistic is higher than the significance $\mathrm{T}$ value, it means the hypothesis is supported or accepted. The study used a confidence rate of 95 percent or a significant level=5 percent, hence the significance $\mathrm{T}$ value for the two-tailed hypothesis was $1.96[22][23]$.

Table 5. Hypothesis testing results

\begin{tabular}{|c|l|c|c|c|c|}
\hline & \multicolumn{1}{|c|}{ Influence between Variables } & $\begin{array}{c}\text { Coefficient } \\
\text { Path }\end{array}$ & $\begin{array}{c}\mathbf{T} \\
\text { Statistics }\end{array}$ & $\begin{array}{c}\text { T } \\
\text { significance } \\
\mathbf{0 . 0 5}\end{array}$ & Verdict \\
\hline H1 & $\begin{array}{l}\text { Transformsional Leadership Style of } \\
\text { Employee Performance } \rightarrow\end{array}$ & 0.550 & 9.849 & 1,96 & Significant \\
\hline H2 & $\begin{array}{l}\text { Employee Performance Work } \\
\text { Commitment } \rightarrow\end{array}$ & 0.433 & 5.511 & 1,96 & Significant \\
\hline H3 & $\begin{array}{l}\text { Leadership Style Transformsiona Kerj } \\
\text { Commitment } \rightarrow\end{array}$ & 0.365 & 4.397 & 1,96 & Significant \\
\hline
\end{tabular}

Source: SmartPLS Output, 2021 
If value $t$ count $>t$ Significant so evident exist influence Significant between variable Exogenous to Endogenous Instead if value $t$ count $<\mathrm{t}$ Significant, so evident not exist influence Significant escort variable Exogenous to Endogenous. Table 5 show from three (3) Hypothesis that Filed all evident Significant.

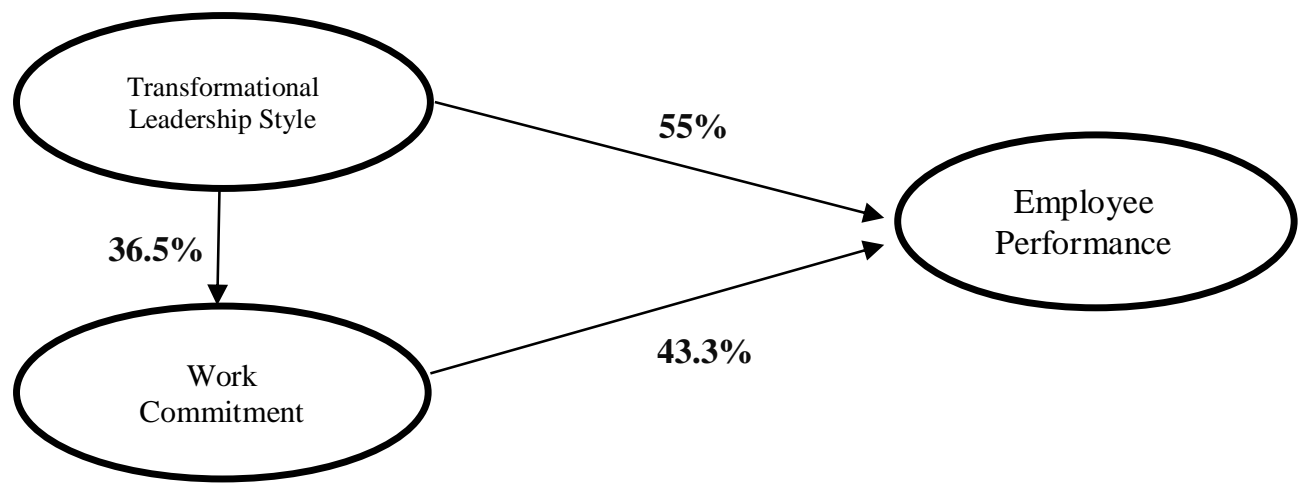

Figure 2. End model of research

The first hypothesis test is performed to test the effect of Transformational Leadership Style variables on Employee Performance variables. Proof of the presence or absence of significant influence is done by comparing the t-statistical value of the result of bootstrapping with t significance of 5\%. Based on table 5.37, known value $t$ calculates $>t$ significance 5\%, namely: 9,849>1.96. It can be concluded that transformational leadership styles proved to have a significant effect on employee performance variables at a significance level of 5\%. Thus the first hypothesis is accepted the truth. The coefficient of the direction of the relationship is positive, meaning that if the Transformational Leadership Style is good, it will improve Employee Performance, on the contrary, the more bad that the Transformational Leadership Style, it will decrease Employee Performance. The results of this study support the results of research conducted by Anca Vacar and Miricescu (2015) which also proves in the study concluded Transformational Leadership Style has a significant effect on Employee Performance.

The second hypothesis test is conducted to test the effect of the Work Commitment variable on employee performance variables. Proof of the presence or absence of significant influence is done by comparing the t-statistical value of the result of bootstrapping with t significance of 5\%. Based on table 5.37, the value of $t$ calculates $>t$ significance 5\%, namely: 5,511>1.96. It can be concluded that work commitment proved to have a significant effect on employee performance variables at the level of significance of 5\%. Thus the first hypothesis is accepted the truth. The coefficient of the direction of the relationship is positive, meaning that if the Work Commitment is good, it will improve employee performance, on the contrary, the more not good that the Work Commitment, it will decrease employee performance. The results of this study support the results of research conducted by Prima Nugraha S (2012) which also proves in the study concluded work commitment has a significant effect on employee performance.

The third hypothesis test is performed to test the effect of transformational leadership style variables on the Work Commitment variable. Proof of the presence or absence of significant influence is done by comparing the t-statistical value of the result of bootstrapping with t significance of 5\%. Based on table 5.37, it is known that the value of $t$ calculates $>t$ significance of 5\%, namely: 4,397>1.96. It can be concluded that transformational leadership styles proved to have a significant effect on the work commitment variable at a significance level of 5\%. Thus the first hypothesis is accepted the truth. The coefficient of the direction of the relationship is positive, meaning that if the Transformational Leadership Style is good, it will increase work commitment,otherwise the more bad that theTransformational Leadership Style, it will decrease the Work Commitment. The results of this study support the results of research conducted by Anca Vacar and Miricescu (2015) which also proves in the study concluded Transformational Leadership Style has a significant effect on Work Commitment.

\section{CONCLUSION}

Based on the results, analysis and discussion, the conclusion of this study is (1) Transformational Leadership Style has a significant effect on Employee Performance in the Regional Secretariat of Murung Raya Regency of Central Kalimantan,(2) Work Commitment has a significant effect on Employee Performance in the Regional Secretariat of Murung Raya Regency of Central Kalimantan, and (3) Transformational Leadership Style has a significant effect to the Work Commitment to the Regional Secretariat of Murung Raya Regency of Central Kalimantan. 


\section{ACKNOWLEDGEMENTS}

The author expressed his deepest gratitude to the Regional Secretariat of Murung Raya Regency of Central Kalimantan who has provided the research site and supported this research.

\section{REFERENCES}

[1] Stoner, James A. F; Freeman, R. Edward; Gilbert JR, Daniel. R. Management, Jilid I, PT Bhuana Ilmu Populer, 1996.

[2] Stoner, James A. F; Freeman, R. Edward; Gilbert JR, Daniel. R. Manajemen", Jilid II, PT Bhuana Ilmu Popular, 1995.

[3] Su'ud, Muh. Persepsi Sosial Tentang KredibilitasPemimpin, Sinergi Studi Bis nis andManajemen, Vol.3, No.1. Things 51-65, 2000.

[4] Thoha, M., Kepemimpinan dalamManajemen,A Pendekatan Perilaku, Rajawali Press, Jakarta, 2001.

[5] Vacar, Anca and Miricesco. Leadership - A Key Factor to a Succesfull Organization - Part II. Journal of Revista Economica. Vol.66, 2015.

[6] Herold, David M. et al. The Effects of Transformational and Change Leadership on Employee's Commitment to a change: A Multilevel Study. Journal of Applied Psychology. Vol. 93. No.2. 346-357, 2008.

[7] Ismail, Azman et al. Transformational and Transactional Leadership Styles as a Predictor of Individual Outcomes. Journal Theoritical and Applied Economics. Vol.XVII. No.6, pp. 89-104, 2010.

[8] BPKP. Performance Measurement, A Review of Government Agencies, Government Agency Performance Accountability System Development Study Team, Jakarta, 2000.

[9] Mas'ud, Fuad. 40 Myths of Human Resource Management. Semarang: Diponegoro University Publishing Body, 2002.

[10] McNeese-Smith, Donna. Increasing Employee Productivity, Job Satisfaction and Organizational Commitment. Hospital and Health Services Administration. Vol. 41:2, 1996.

[11] Lodge B. and C. Derek. Organizational Behavior and Design. Translation of Sularno Tjiptowardoyo, Gramedia, Jakarta. 1993.

[12] Luthans, Fred. Organizational Behavior, (V.A. Yuwono Language Transfer, et al),Edition. Indonesian. Jakarta: Erlangga, 2006.

[13] Husein Umar, Application Research Methodology in Marketing, PT Gramedia Pustaka Jakarta, 1999.

[14] Sugiyono. Qualitative Quantitative Research Method and R\&D. Bandung: ALFABETA, 2008.

[15] Djarwanto PS dan Subagyo, Pangestu. Statistik Induktif,Edisi keempat, BPFE, Yogyakarta. 1998.

[16] Cooper, Donald R. and Pamela S. Schindler. Business Research Methods. Jakarta: PT Media Global Pendidikan, 2006.

[17] Wong, K.K. Partial Least Square Structural Equation Modelling (PLS-SEM) Tecniques Using Smart PLS. Mark. Bull. Vol 24, 2013.

[18] Ferdinand, Augusty. StructuralEquation ModelingDalam Penelitian Manajemen, Badan Penerbit Universitas Diponegoro, 2006.

[19] Hair, J.F.,Jr.,R.E. Anderson, R.L., Tatham \& W.C. Black. Multivariate Data Analysis With Readings, Englewood Cliffs, NJ: Prentice Hall, 1995.

[20] Solimun. Structural Equation Modelling (SEM) Lisreldan Amos. Malang: FMIPA Universitas Brawijaya, 2013.

[21] Gendro, Wiyono. Designing Business Research with SPSS Analysis Tool 17.0 \& Smart PLS 2.0. Yogyakarta: Printing STIM YKPM, 2011.

[22] Chin, W. W. The Partial Least Squares Aproach to Structural Equation Modeling. Modern Methods for Business Research, 295, 336, 1997.

[23] Ghozali, Imam. Structural Equation Modeling Alternative Methods With Partial Least Square. Diponegoro University Publishing Body, Semarang, 2006. 


\section{BIOGRAPHIES OF AUTHORS}

Yohana, S. IP., M. AP. Lahir in Buntok, December 18, 1985. Completed Bachelor (S1)
Government Science, FISIP STPMD "APMD" Yogyakarta and continued his education in the
Master Program (S2) of Public Administration Science Faculty of Social and Political
Sciences, Lambung Mangkurat University, Banjarmasin South Kalimantan. The author works
as State Civil Apartment (ASN) in the Regional Secretariat of Kab. Murung Raya. The
author is domiciled in Puruk Cahu, Kab. Murung Raya, Central Kalimantan. The author can
be contacted by email: hannajoanne69@yahoo.com

